\title{
Creating Memorandums of Understanding/Agreement with Affiliate Organizations of $4-\mathrm{H}^{1}$
}

Marilyn N. Norman and Joy C. Jordan²

A Memorandum of Understanding (MOU) or a Memorandum of Agreement (MOA) has become a tool to articulate and recognize collaborations and partnerships between affiliate organizations that provide support to the 4-H Youth Development Program of Cooperative Extension Service (CES) and $4-\mathrm{H}$.

4-H Programs at the national, state, and county levels partner with and create many affiliate volunteer-based groups. These groups often are organized specifically to promote and carry out the mission of the 4-H program. Therefore, they need to have written authorization to use the name and emblem. An MOU can provide this authorization and give more details on the rights and responsibilities that are associated with the use of the 4-H Name and Emblem.

A Memorandum of Understanding (MOU) is simply a written agreement to identify the working relationships and guidelines between collaborating or patterning entities. An MOU spells out the common understandings. It clarifies what kind of support will be provided and creates more meaningful ways for communication or participation. It defines the rights and responsibilities of each involved entity. Sometimes an MOU is also called a Memorandum of Agreement (or MOA). MOUs and MOAs are sometimes used interchangably.
Here are some typical components of an MOU, with sample language:

\section{Purpose and Agreement(s)}

The memorandum should state the purpose and goals of the collaboration or partnership between the two entities. The specific agreements should be detailed into separate paragraphs or listings along the lines of "What [X Agency] Will Do" and "What [Y Group] Will Do."

\section{Duration or Term of Memorandum and Termination Process}

The memorandum should identify the beginning and ending dates of the agreement or its duration.

\section{Example:}

This memorandum shall commence on [date] and shall continue for period of [ending date/number of years].

or

This MOU will remain in effect until modified or terminated by any authorized official of 4- $\mathrm{H}$ and [affiliate group].

The memorandum should also identify how the MOU can be terminated.

\footnotetext{
1. This document is 4H 2.5, one of a series of the Florida 4-H Program, Florida Cooperative Extension Service, Institute of Food and Agricultural Sciences, University of Florida. First published January 2007. Please visit the 4-H Website at http://4h.ifas.ufl.edu/Curriculum/index.htm.

${ }^{2}$ Marilyn N. Norman, Associate Professor, Department of Family, Youth and Community Sciences, and State 4-H Program Leader, and Joy C. Jordan, Associate Professor, Department of Family, Youth and Community Sciences, Institute of Food and Agricultural Sciences, University of Florida, Gainesville.

The Institute of Food and Agricultural Sciences (IFAS) is an Equal Employment Opportunity - Affirmative Action Employer authorized to provide research, educational information and other services only to individuals and institutions that function without regard to race, creed, color, religion, age, disability, sex, sexual orientation, marital status, national origin, political opinions or affiliations. For information on obtaining other extension publications, contact your county Extension Service office. The Florida 4-H Program is the youth development program of the Florida Cooperative Extension Service/Institute of Food and Agricultural Sciences/University of Florida/Larry R. Arrington, Dean.
} 


\section{Example:}

This memorandum may be terminated by either party giving the other party [three months'] notice in writing.

In addition, the memorandum should identify amendment processes.

\section{Example:}

This memorandum may be amended or varied from time to time if such amendment or variation is evidenced in writing and signed by the parties.

\section{Meetings and Reporting}

An MOU describes the interaction between the other organization and the County 4-H Program. It provides a structure, such as a specific meeting time, or the "as needed" informal expectations of either party. It is also a way for parties to specify their reporting needs and timeframes.

\section{Example:}

To accomplish the purpose and objective set forth in the MOU, partners will meet at least [twice] a year.

\section{Financial Considerations}

The financial or funding support situation should be explained. Someone may need to take responsibility for financial record keeping and reporting. Specify who will review and approve expenditures and financial decisions on behalf of the collaboration, if needed.

Here are a few examples of statements for program collaborations or partnerships where funding is not part of the agreements:

Nothing in this MOU shall be deemed to be a commitment or obligation of funds from either 4-H or [affiliate group] (or any of their various components).

The entities acknowledge that all or any financial arrangements must be negotiated and will depend upon the availability of funds.

\section{Signatures with Dates}

Once the MOU is prepared and agreed upon by parties involved, it should be signed and dated by the authorized individuals representing each partner or organization. Copies should be kept in an easily accessible location by both entities.

\section{The Value of Preparing an MOU with Affiliate 4-H Groups}

In addition to officially recognizing 4-H Affiliate Groups and authorizing their use of the 4-H Name and Emblem, an MOU is important because it:

Sets a better tone for participation. Creating an MOU makes both partners more familiar with the 4$\mathrm{H}$ Name and Emblem regulations.

Negotiating an MOU raises both entities' awareness about their responsibilities to involve the other entity in decisions or program policies. It also gives organized program participants the opportunity to define participation in ways that are truly meaningful to them.

Builds a stronger working relationship. The process of actually negotiating an MOU helps participant entities and 4-H/CES faculty build a better working relationship, better listening skills, and more empathy for the issues that the other group faces. Participants develop a better understanding of the challenges the 4-H Program deals with-for example, working with limited budgets. Likewise, the 4-H Program staff develops a better understanding of the problems clientele groups and community organizations face and their ideas for solutions that will work in their community.

Sets up a structure for a partnership. An MOU puts the partnership between the other organization and the County 4-H Program in writing. It provides a structure for a working relationship. For example, the MOU can establish a specific meeting time, which may be preferable to relying on the "as needed" informal expectations of either party.

Clarifies how regulations will be interpreted. While state policies and rules may provide a framework for clientele participation, an MOU can clarify how your program will carry out its responsibilities under these policies and rules. For example, guidelines say the County 4-H Program must ensure "open communications" with the clientele organization. An MOU can clarify that 
"open communications" will be defined as access to specific documents, advance notice of any changes in policies, and responses in writing from the County 4-H Program to written comments submitted by a clientele group or organization.

A specific example of the regulations that may need to be explained in an MOU is the use of the 4-H Name and Emblem in marketing and promoting programs. An MOU provides a means to clarify how and under what conditions affiliated groups can use the 4-H Name and Emblem.

Protects organizations' rights over time. Your current organization may have a good working relationship with the current program director of a given community group, but what if a new director comes in who is less open to participant involvement? Or what if the leadership in the clientele organization changes and becomes less democratic? An MOU protects both groups over time, because it makes it clear that the group has certain rights no matter who is in the current leadership role.

\section{Resources}

For additional resources on authorizing groups to use the 4-H Name and Emblem, and for samples of MOUs, go to the Faculty and Staff section of the Florida 4-H web site at http://www.florida4h.org.

For additional resources on financial and fiscal accountability of 4-H Clubs and Affiliate Groups, refer to the 4-H Financial Management Fact Sheets (4H 5.0 through 4H 5.8) or Section 5 of the Florida 4-H Program Handbook, which is located in the Faculty and Staff section of the Florida 4-H Web site at http://www/florida4h.org. 
The following are examples of templates with sample language for Memorandums of Understanding (MOU). Please note that other sections may need to be added, depending on the nature of the agreement and the parties involved. The duties and responsibilities of each party should be clearly defined. Please state what is to be done or what is expected in plain, simple language. Be specific about any financial or other resource obligations of each party and include the dates when the actions are to be taken and completed. Be sure to include a statement regarding the use of the 4-H Name and Emblem, the rights and responsibilities that entails, and the conditions under which this use may be revoked and this memorandum terminated.

\section{SAMPLE}

\section{Joint Programming MOU between 4-H and Parks and Recreation}

\section{INTRODUCTION}

4-H is the youth development program of the Cooperative Extension System of the University of Florida, the USDA Cooperative State Research, Educational and Extension Service and County. The County Parks and Recreation Department is and provides activities and services for school-age children in the city of

Both of these county-sponsored youth programs agree that expanding the number and improving the quality of programs to benefit county citizens through a partnership of 4-H and Parks and Recreation is desirable.

\section{PURPOSE}

This Memorandum of Agreement establishes the guidelines for collaboration between 4- $\mathrm{H}$ and the County Parks and Recreation Department to 1) plan and promote summer day camps and 2) increase the number of available after-school programs by providing three after-school 4-H clubs.

\section{Agreement:}

The ___ County Parks and Recreation Department and 4-H hereby agree to work together to:

1.

2.

3.

4.

5.

6. Jointly identify and support reporting requirements of each organization.

7. Jointly respect and acknowledge the work of both organizations at the local, county, state, or national levels to help communicate successful partnership efforts.

\section{MEETINGS AND REPORTING}

To accomplish these objectives, partners will meet at least times a year for the purposes of program planning and monitoring and evaluating outcomes.

FUNDING and Financial Responsibilities:

For Summer Day Camp Programming, the County Parks and Recreation Program will provide:

For Summer Day Camp Programming, the County 4-H Program will provide:

For 4-H After-School Programs, 4-H will provide: 


\section{DURATION:}

This MOU is at-will and may be modified with the mutual consent of the authorized individuals of 4-H and County Parks and Recreation Department. Once signed by authorized officials of both groups, this MOU will begin [Month Day, Year] and remain in effect until [Month Day, Year].

Signed,

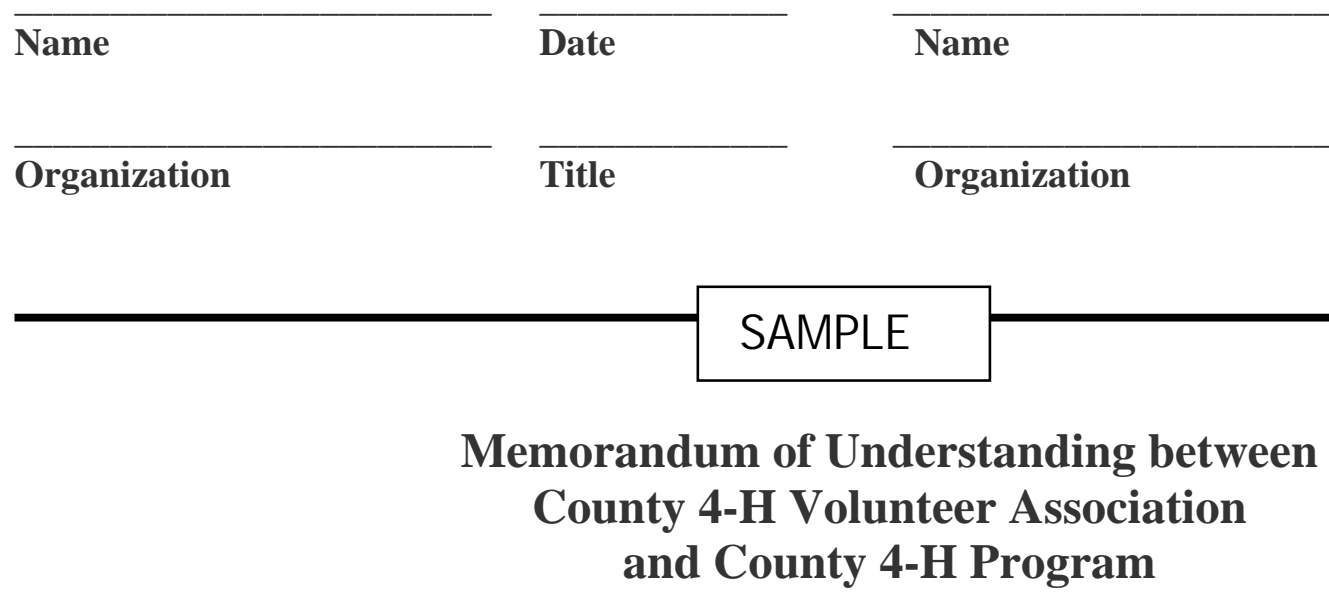

\section{INTRODUCTION}

4- $\mathrm{H}$ is the youth development program of the Cooperative Extension System of the University of Florida, the USDA Cooperative State Research, Educational and Extension Service and County. The

County 4-H Volunteer Association provides activities and support for 4-H volunteers in county. The County Extension Service 4-H Program supports expanding the number and quality of programs to benefit 4- $\mathrm{H}$ volunteers through a partnership of $4-\mathrm{H}$ and the County 4-H Volunteer Association.

\section{PURPOSE}

This Memorandum of Agreement establishes the guidelines for collaboration between County 4-H Volunteer Association.

4-H and the

\section{Agreement:}

The ___ County Volunteer Association and the County 4-H Program hereby mutually agree to work together to:

1. Recruit and promote volunteer opportunities to support the County 4-H Youth Development Program.

2. Support volunteers and youth as partners in planning, implementing, and evaluating 4-H Youth Programs within County.

3. Provide multiple opportunities to recognize volunteers for their contributions to the County $4-\mathrm{H}$ Program.

4. Strategically leverage resources to enhance volunteer training and development.

5. Provide leadership to and support the Florida 4-H Policies and Guidelines.

6. Use the 4-H Name and Emblem in accordance with the federal law, regulations, and guidelines regarding use of the 4-H Name and Emblem.

The County 4-H Program agrees to:

1. Provide regular [monthly] communications through correspondence, newsletters, training clinics and workshops to 4-H club volunteers.

2. Provide periodic new leader/volunteer orientation clinics to support the success of newly recruited 4H Volunteers. 
3. Designate a staff representative to serve on the Volunteer Association Board in an ex officio manner to foster cooperation and understanding between the Volunteer Association and the County Extension 4-H Youth Program.

4. Seek input from and representatives of the County Volunteer Association to serve on planning committees, advisory boards and other opportunities to foster collaborative relationships and communication with 4-H volunteers.

5. Provide training and support to the members of the association regarding program and fiscal accountability on an annual basis.

The Volunteer Association agrees to:

1. Develop relationships and communication between 4-H volunteers, County Extension Agents and the County 4-H Advisory Board.

2. Provide an opportunity for a designated County Extension Agent to serve as an ex officio member of the County Volunteer Board to foster collaboration and build relationships between the Association and the County Extension 4-H Program.

3. Support and help implement the Florida 4-H Volunteer Recruitment, Screening, and Risk Management policies and guidelines.

4. Support and follow the Florida 4-H Financial Guidelines for Volunteers, Fiscal Responsibilities, and Guidelines.

\section{MEETINGS AND REPORTING}

To accomplish these objectives, partners will meet at least __ times a year for the purposes of program planning and monitoring and evaluating outcomes.

\section{FUNDING and Financial Responsibilities:}

\section{DURATION:}

This MOU will begin [Month Day, Year] and remain in effect until [Month Day, Year] upon signatures of the authorized individuals of the organizations.

Signed,

President, County Volunteer

Date:

Association

County Extension 4-H Agent

Date:

Date:

CED, County Extension Service 


\section{SAMPLE}

\section{MEMORANDUM OF UNDERSTANDING between County 4-H Program and County Fair Board}

THIS IS A MEMORANDUM OF UNDERSTANDING, made and entered into by and between the County Extension 4-H Youth Program (herein referred to as 4-H) and the County Agricultural

Fair Board (hereinafter referred to as "Fair Board").

WHEREAS, the Congress of the United States enacted legislation in 1914 known as the Smith-Lever Act, providing for Cooperative Extension Work; and

WHEREAS, the United States Department of Agriculture and the County Extension Director (CED/4-H) are responsible for the authorization and uses of the "4-H" Emblem and/or the words "4-H Clubs";

WHEREAS, [insert language relevant to Fair Authority from Florida Department of Agriculture and Consumer Affairs] and [Local Fair Board formation in county];

THEREFORE, in order to provide cooperative support, to conduct, and to administer, the 4-H and the Fair Board mutually agree on the following policies and procedures:

\section{Agreements}

\section{County Extension Director/4-H Program agrees:}

1. To provide administrative leadership to the 4-H and Extension portion of the County Fair program within the County.

2. That the CED will provide supervision to its Extension faculty, staff and volunteers operating in conjunction with 4-H. All such staff shall be subject to employment procedures and policies pertaining to University of Florida or the county.

3. That the program shall be conducted in accordance with provisions of the Smith-Lever Act as amended, and all applicable state statutes and local laws. The 4-H program shall be available to youth from ages of 5 to 19, and shall not illegally discriminate against its participants based upon race, color, sex, religion, national origin, disability or sexual orientation.

4. That the supervision and administration of the 4-H Name and Emblem will be in accordance with the federal law, regulations, and guidelines regarding use of the 4-H Name and Emblem.

5. To facilitate providing a staff of qualified 4-H volunteers to assist in the planning and implementation of a 4-H education program at the County Fair.

6. To determine the qualifications and eligibility for 4- $\mathrm{H}$ participants and prepare recommendations for classes, events, and activities that will add to the quality of the learning experience at the fair.

7. To provide the educational program and the criteria for the programming of 4-H events, activities, and contests.

8. To accept responsibility for a 4-H appeals process in cooperation with the Fair Board. 


\section{Fair Board agrees:}

1. To assume leadership for the selection and election process of the Fair Board and its officers.

2. To assume responsibility for the financial stature of the Fair Board and to provide financial support for 4-H classes and events.

3. To review and support the recommendations from 4-H educational programming for deletions and additions to the County Fair 4-H program.

4. To attach the 4-H Name and Emblem to those programs, and only those programs, that 4-H has identified as 4-H programs, in accordance to State and Federal Rules

5. To assume responsibility for selection of judges in cooperation with 4-H for appropriate evaluation of 4-H projects, contests, and events.

6. To support the appeals and protest procedures of 4- $\mathrm{H}$ for entries as determined by the County 4-H Program.

7. To provide exhibit areas, work and storage space, ribbons, and premiums to support an effective program.

8. To invite Extension staff and 4-H volunteers to attend all meetings of the Fair Board and contribute to County Fair plans.

\section{Funding:}

Performance under this Memorandum or any program or project arising from the terms of this Memorandum may likely rely upon the support of public funding. Should such funding be jeopardized as a result of legislative action, local county board action, or other means of changing the law, this Memorandum may be void or amended in order to comply with any change in law.

\section{Duration:}

This Memorandum shall be in effect upon execution by all the parties and shall remain in force until it is rescinded in writing by any one of the parties no later than 180 days prior to the first day of the County Fair.

\section{Signatures:}

The undersigned warrant that they are duly authorized on behalf of the body they represent to sign this Memorandum and bind their respective parties to the terms of this Memorandum.

Date

County Extension Director

Date

$$
\overline{\text { President, County Agricultural Fair Board }}
$$

